\title{
A Fine Investigation on Geological Conditions for Oil Accumulation in the Paleogene Intersalt Shale Series in the Qianjiang Depression
}

\author{
Xiaolong Ju${ }^{1}$, Junjun Shen ${ }^{2 *}$, Shourui Zhong1, Weihao Zhang' ${ }^{1}$, Jiaqi Liu' ${ }^{1}$, Fansong Wei ${ }^{1}$ \\ ${ }^{1}$ College of Geophysics and Petroleum Resources, Yangtze University, Wuhan, China \\ ${ }^{2}$ Hubei Cooperative Innovation Center of Unconventional Oil and Gas of Yangtze University, Wuhan, China \\ Email: 929915845@qq.com, *705194434@qq.com
}

How to cite this paper: Ju, X.L., Shen, J.J., Zhong, S.R., Zhang, W.H., Liu, J.Q. and Wei, F.S. (2019) A Fine Investigation on Geological Conditions for Oil Accumulation in the Paleogene Intersalt Shale Series in the Qianjiang Depression. Open Journal of Yangtze Gas and Oil, 4, 301-312. https://doi.org/10.4236/ojogas.2019.44024

Received: September 4, 2019

Accepted: October 11, 2019

Published: October 14, 2019

Copyright $\odot 2019$ by author(s) and Scientific Research Publishing Inc. This work is licensed under the Creative Commons Attribution International License (CC BY 4.0).

http://creativecommons.org/licenses/by/4.0/ (c) (i) Open Access

\begin{abstract}
This study dealt with the rhythmic Qian $3_{4}{ }^{10}$ of the intersalt shale series in the Qianjiang Depression, in which the geological condition for oil accumulation in the rhythmic shale was investigated by using the basic drilling, core and well logging data, as well as data obtained from the thin section identification, SEM, mercury injection, X-ray diffraction and rock freezing heat analyses. The study result indicated that: 1) the intersalt shale series are characterized by TOC in a range of $0.35 \%-6.38 \%$ (averaging $3.19 \%$ ), Types I and II 1 organic matter, and from immature to mature oil, indicative of a potential for generating a great volume of immature oil; 2) in the target layer, mineral compositions are complicated, which can divide into argillaceous dolomite facies, argillaceous limestone facies, dolomitic mudstone facies, and calcium-mirabilite-filling dolomitic mudstone facies; and 3) of them, the argillaceous dolomite facies is the most contributory, with reservoir spaces consisting of intergranular pores as dominant, as well as rare dissolution pores and seams. It is characterized by high organic abundance $(4.23 \%-6.38 \%)$, high content of brittle mineral (50\% - 71\%), low content of clay mineral (18\% - 33\%), high porosity $(10.8 \%-26.3 \%)$ and good oil-bearing properties (S1 distributed in $3.48-5.64 \mathrm{mg} / \mathrm{g}$, and S1/TOC value in a range of 348 - 564 oil $\mathrm{mg} / \mathrm{g}$ ). Therefore, the argillaceous dolomite facies was considered the key target series to be explored for the intersalt shale oil in the study area in the coming days.
\end{abstract}

\section{Keywords}

Qianjiang Depression, Intersalt Shale Series, Geological Conditions for Hydrocarbon Accumulation, Unmature Oil, Argillaceous Dolomite, Source Rock, Target Series 


\section{Introduction}

Shale oils often occur in effective hydrocarbon-generating shale series in free, adsorbed and dissolved states [1] [2]. They are in-situ retained oil and gas resources [2] [3]. The successful development of shale oils in North America attracted China to concern the shale oils in China. For example, the intersalt shale series of the Qianjiang Formation in the Qianjiang Depression of the Jianghan Basin in China is well-developed with oil and gas shows so abundant that oil immersions occur over the depression [4] [5]. Up to date, chromatography of the intersalt shale showed that a number of wells contributed commercial oil flows at initial rates of $0.9-66.75 \mathrm{t} / \mathrm{d}$, indicative of a tremendous resource potential. However, the intersalt shale has been previously studied using the same methodologies as those used to deal with conventional reservoirs, thus obtaining unsatisfied results [6]. The insight conversion from "the conventional intersalt nonsandstone reservoir" to "the unconventional intersalt shale series" bought about a conclusion that the intersalt argillaceous dolomites did not only provide the main sources for oil and gas generation, but also the main spaces allowing oil and gas to be inhabited [7] [8]. Therefore, how to perform a systematical study on the intersalt shale oil regarding the geological conditions for oil accumulation is essential to boost the exploration and development of the shale oils in the Jianghan Basin. This paper presented an investigation on the rhythmic layer Qian $3{ }_{4}{ }^{10}$ of the intersalt shale series in the Qianjiang Depression, with respect to petro-minerology, hydrocarbon-generating conditions, reservoir conditions and oil/gas-bearing conditions, for the purpose of discussing the geological conditions for hydrocarbon accumulation, and revealing the interest in the depression.

\section{Regional Geological Setting}

The Qianjiang Depression is located in the center of the Jianghan Basin, which was an inland arid rift lake basin originated on the Paleozoic and basement, with an area of about $2500 \mathrm{~km}^{2}$. The depression is bounded by the Yuekou low relief on the east and by the Yajiao low relief on the west. It is controlled by the North Qianjiang Fault in the northwest, and by the Tonghaikou Fault in the south. Due to extensional shear, a NE-trending fracture system occurs in the study area (Figure 1), forming a tectonic framework with one concave between two slopes [6] [9] [10] [11]. In the depression, the Cretaceous-Paleogene strata were deposited, which ascendingly consist of the Cretaceous Yuyang Formation, the Paleogene Shashi, Xingouzui, Jingsha, Qianjian and Jinghezhen Formations, the Neocene Guanghuasi Formations, and the Quaternary Pingyuan Formation (Figure 1). Of them, Unconformities occur between the Pingyuan and Guanhuasi Formations and between the Guanhuasi and Jinghezhen Formations.

The late Eocene to early Oligocene represented the peak period for development of the Jianghan salt lake. The Qianjiang Depression in the center of the basin acted as a depocenter, catchment center and concentration center of the lake basin [12]. In the northern part, an environment with one-way prove- 
nance drainage, high salinity and strong evaporation, the Qianjiang Formation was deposited as thick as $6000 \mathrm{~m}$ [6], forming rhythmic layers consisting of intersalt thin-layered, frequently interbedded mudstones, sandstones, carbonates and evaporates [13]. For each rhythmic layer, a roof plate is separated from the floor plate by a thick salt rock layer, forming a unique petroleum system. Laterally, from the northwest to southeast, sand-mudstone facies area, salt-fresh transition area and salt-lake sedimentary area are present successively. This study area is located in the belt of the Banghu, Wangchang, Zhouji and Guanghua regions. It is a transition belt from salt to fresh water. Vertically, the lithologic association consists of shales with carbonates or thin-layered sandstones, which represents a main area where intersalt shale series are present. The northwestern part is covered by deltaic sand and mudstone sediments, which is vertically characterized by frequent thin interbeds of sandstones and mudstones. The salt lake sedimentary area in the southeast is occupied by salt rocks, glauberites with mudstone sediments [6]. The Qianjiang Formation, in ascending order, can be divided into the Qian 4, 3, 2, and 1 Members. The target layer in the study area is located in the $10^{\text {th }}$ rhythmic layer of the $4^{\text {th }}$ sublayer of the Qian 4 Member (thereafter simplified as the rhythmic layer Qian $3_{4}{ }^{10}$ ). When it was deposited, the lake basin was characterized by subsidence of the fault depression with a weak faulting activity, and a gentle topography thinning to south from north, and to slope from center [14].

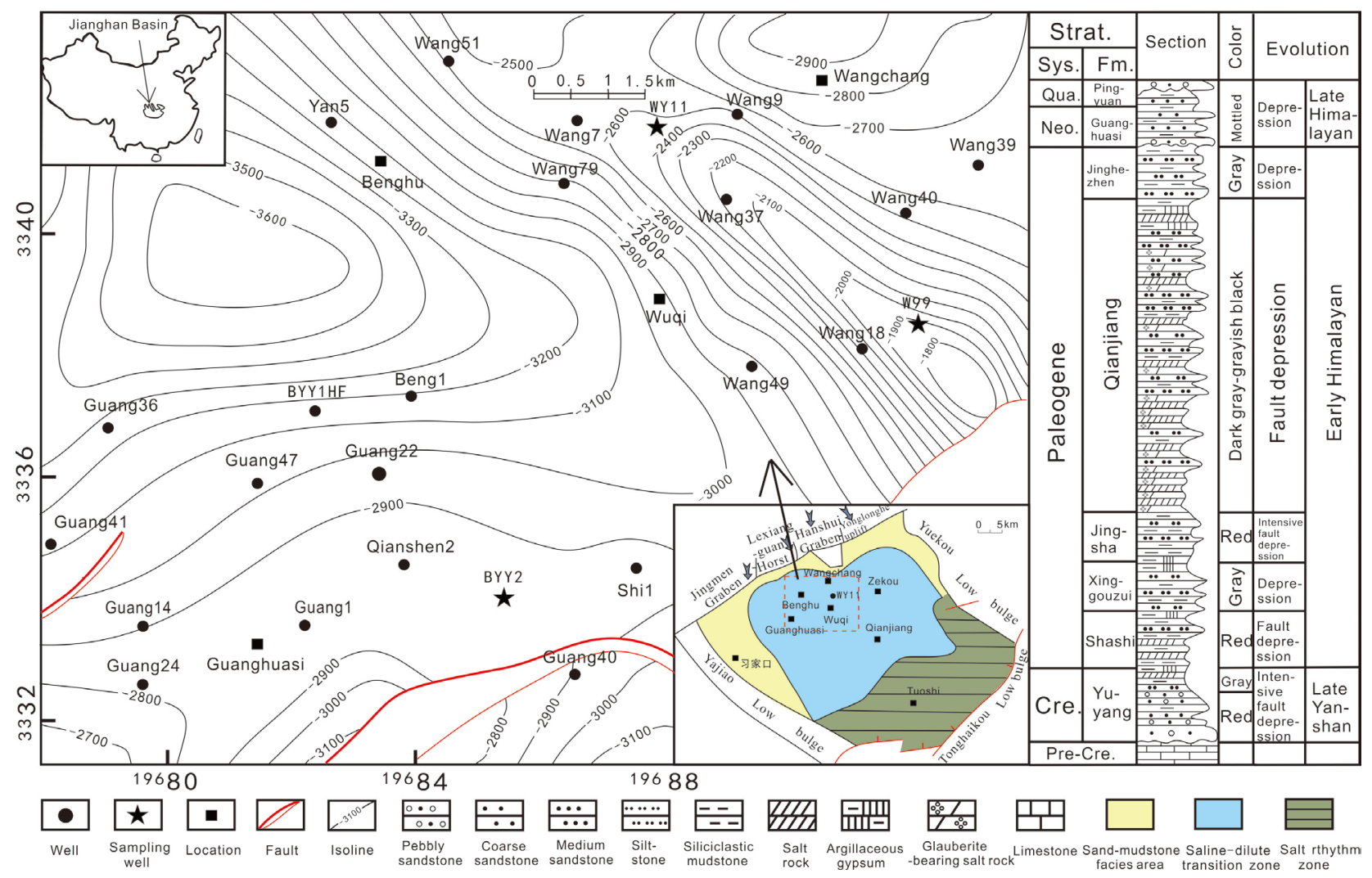

Figure 1. Map showing the location of the study area, distribution of wells, sedimentary environment, with the stratigraphic sketch for the Qianjiang Depression. 


\section{Sampling and Analysis Experiment}

A total of 106 samples for this study were cored from the Paleogene rhythmic layer Qian $3_{4}{ }^{10}$ in 3 wells across the Banghu-Wangchang area, including 52 samples from 99 wells, 20 from Well BYY2, and 5 from Well WY11. Thin sections of the all samples were identified under the conventional SEM, in order to ensure a reliable classification and analysis. On this basis, the residual samples were selected for SEM, microscopic analysis of kerogen compositions, vitrinite reflectance, $\mathrm{X}$-ray diffraction, and rock pyrolysis tests. Plunger samples were obtained by drilling on-site for mercury injection, with a diameter of $2.5 \mathrm{~cm}$ and a length of $10 \mathrm{~cm}$. The distribution of the sampling wells is shown in Figure 1.

For this study, analysis and tests, such as thin section identification and sample SEM were performed by the Geological Laboratory of Exploration and Development Institute of the Southwest Oil and Gas Field Company of CNPC. For the conventional thin section identification, the lycra polarizing three-eye microscope (DM2700P) was used. Prior to identification, the samples were treated with the solution mixture of alizarin red and potassium ferricyanide. SEM was perfomed with a field emission environmental scanning electron microscope (JSM-5500).

Additional analyses and tests, such as for kerogen compositions and maturity with SEM, x-diffraction, rock pyrolysis and mercury injection were performed by the Exploration and Development Institute of the SINOPEC Jianghan Oilfield Company and SINOPEC Wuxi Petroleum Geology Institute. The microscopic kerogen compositions were detected with Leica transmission light and reflected light fluorescence microscope (Leica AF6000) at a $24^{\circ} \mathrm{C}$ temperature and humidity of $65 \% \mathrm{RH}$. The vitrinite reflectance was measured with the microphotometer Leica MSP200 at $23^{\circ} \mathrm{C}$ and humidity of $60 \% \mathrm{RH}$. The X-ray diffraction analysis was performed with Phillips Xpert-MPD-typed X-ray diffractometer to determine the mineral spacies and contents in terms of $2 \theta$ angles (a scanning range of $20^{\circ}-40^{\circ}$ ) and spectral peak intensity. The pyrolysis analysis was conducted to detecte by using Rock-Eval6 (rock pyrolysis unit) according to the standard for rock pyrolysis analysis (GB/T18602-2012). The mercury injection was performed with a unit named PoreMaster 33 with an aperture measuring range from $6.4 \mathrm{~nm}$ to $950 \mu \mathrm{m}$.

\section{Experimental Results and Discussion}

\subsection{Characteristics of Lithofacies and Brittleness}

The full rock XRD test indicated that the rhythmic layer Qian $3{ }_{4}{ }^{10}$ in the study area is complicated in mineral composition, which is compound of terrigenous debris, carbonate and evaporite minerals. Vertically, the layer is characterized by a variety of mineral types and high heterogeneity. In order to investigate its vertical minerological variation, the layer can be subdivided into secondary lithofacies consisting of argillaceous dolomite, dolomitic mudstone, argillaceous limestone and glauberite-filling dolomitic mudstone facies, in terms of content 
and attitude of the rock constituents (Figure 2). The development characteristics of these lithofacies are described as follows.

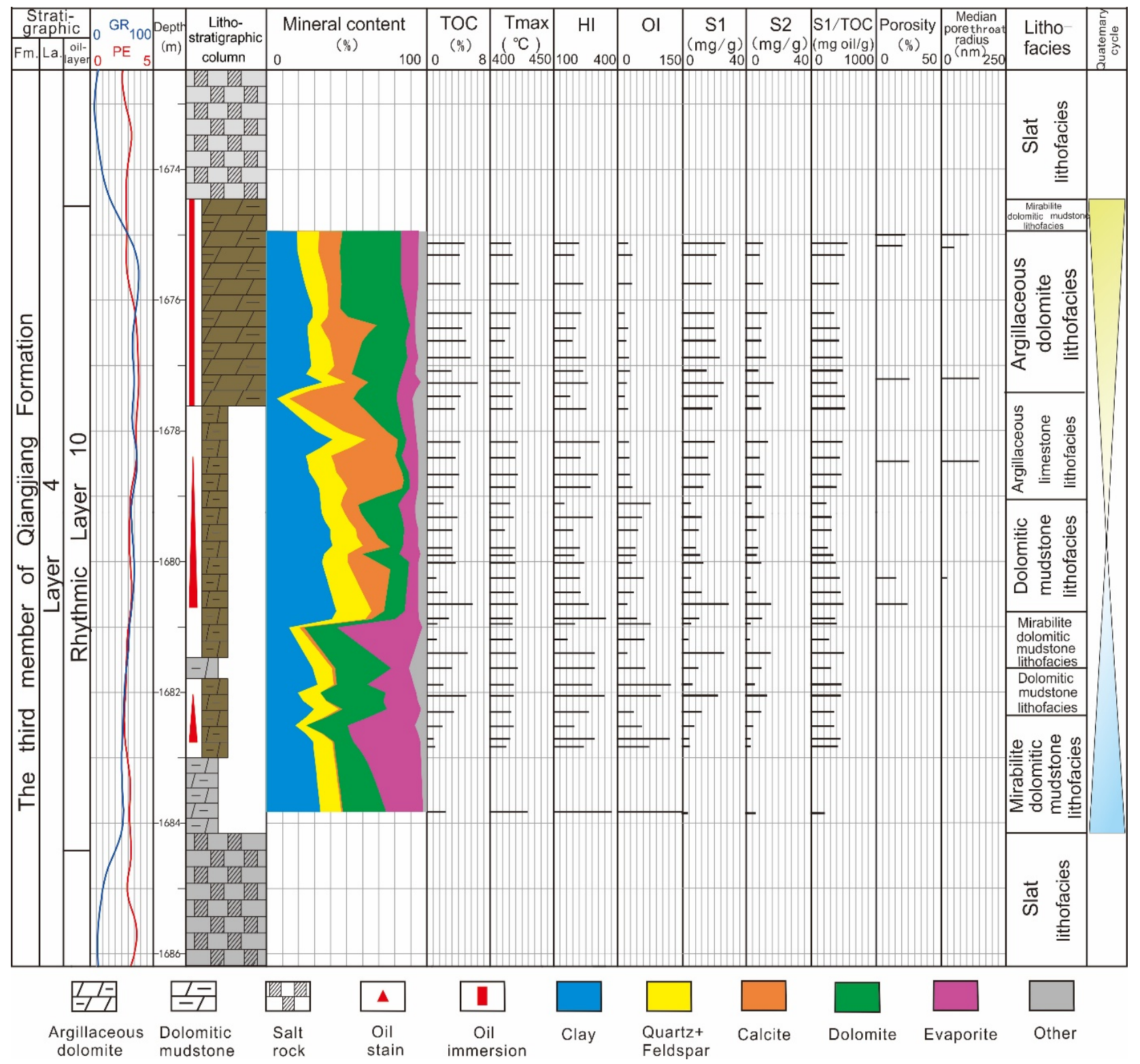

Figure 2. Generalized stratigraphic column for the rhythmic layer Qian $34^{10}$ in well W99.

Argillaceous dolomite facies: This facies is in yellowish-brown color, with obvious oil immersions (Figure 3(a)). Under the microscope, the dolomite is observed to be in a micritic structure, which is xenotopic, with a large quantity of carbon debris (Figure 3(b) and Figure 3(c)). Its mineral compositions are compound of dolomite as high as $20 \%-42 \%$ (averaging $30.5 \%$ ), clay minerals, $18 \%$ - 33\% (averaging 25.4\%), quartz and feldspar, 9\% - 20\% (averaging 13.3\%), as well as evaporite minerals (gypsum and calcium mirabilite as dominant) as low as $1 \%-6 \%$ (averaging 2.3\%), and brittle minerals (quartz, feldspar, dolomite and calcite) as high as $50 \%-71 \%$ (averaging $61.1 \%$ ). 

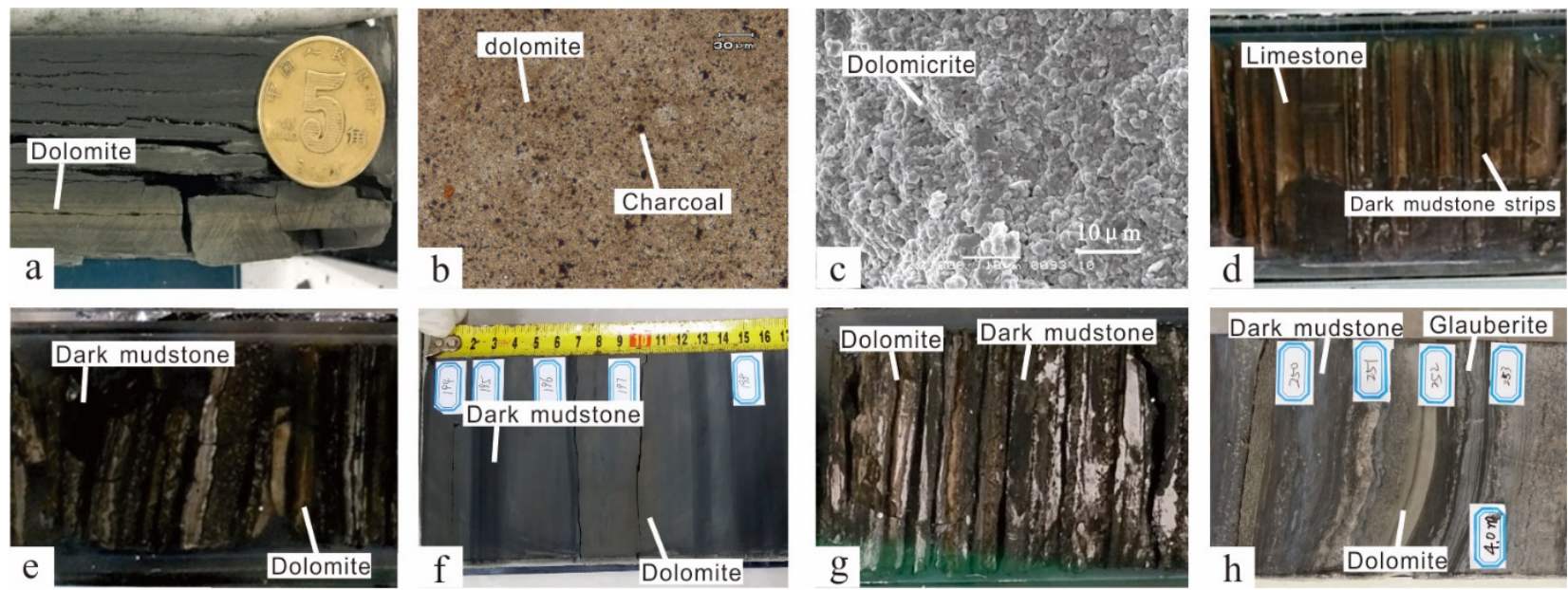

Figure 3. Core and SEM characteristics of petrologic facies for the rhythmic layer Qian $34^{10}$ in Wells W99, BYY2 and WY11. a. Yellowish-brown argillaceous dolomite facies, Well W99, $1676.9 \mathrm{~m}$; b. Micritite-structured dolomite, with much dispersed carbon debris, Well W99, 1675.8 m; c. Dolomite crystals, in micritic structure, xenomorphic, with irregular contact surface, Well WY11, $1749.3 \mathrm{~m}$; d. Argillaceous limestone facies, Well W99, 1678 m; e. Dolomitic mudstone facies, Well W99, 1679.5 m; f. Dolomitic mudstone facies, Well BYY2, 2821.4 m; g. Glauberite-filling dolomitic mudstone facies, Well W99, 1682.4 m; h. Carbon-rich glauberite-filling dolomitic mudstone facies, BYY2 well, $2823.4 \mathrm{~m}$.

Argillaceous limestone facies: This facies is in greyish brown color, with grayish black mudstones non-isopachous interbedded with yellowish brown limestones (Figure 3(d)). Its mineral compositions are compound of calcite as high as $23 \%-41 \%$ (averaging $34 \%$ ), clay minerals, 5\% - 39\% (averaging 28.4\%), quartz and feldspar, $79 \%$ - 21\% (averaging 16.7\%), as well as evaporite minerals (gypsum and calcium mirabilite as dominant) as low as $1 \%-3 \%$ (averaging 2.4\%), and brittle minerals (quartz, feldspar, dolomite and calcite) as high as $48 \%$ - 76\% (averaging 58\%).

Dolomitic mudstone facies: This facies is in greyish brown or yellow brown color. Core observation indicates that it is a non-isopachous interbed of yellowish brown dolomicrite with yellowish brown limestones (Figure 3(d)). Its mineral compositions are compound of calcite as high as $23 \%-41 \%$ (averaging $34 \%$ ), clay minerals, $5 \%-39 \%$ (averaging $28.4 \%$ ), quartz and feldspar, $79 \%$ $21 \%$ (averaging 16.7\%), as well as evaporite minerals (gypsum and calcium mirabilite as dominant) as low as $1 \%-3 \%$ (averaging $2.4 \%$ ), and brittle minerals (quartz, feldspar, dolomite and calcite) as high as $48 \%$ - 76\% (averaging 58\%).

Glauberite-filling dolomitic mudstone facies: This facies is in grey-light gray color, and mostly occurs at the bottom and top of the $10^{\text {th }}$ rhythimc layer (Figure 3(g) and Figure 3(h)). Its mineral compositions are compound of glauberite rocks in a range of 5\% - 54\% (averaging 33.3\%), dolomites, $11 \%-35 \%$ (averaging 22.5\%), clay minerals equivalent to dolomites in content, $13 \%-29 \%$ (averaging 22.5\%), as well as quartz and feldspar, 6\% - 23\%, (averaging $12 \%$ ), and calcite as low as $0 \%-4 \%$, (averaging $2 \%$ ). This facies contains the lowest content of brittle minerals among the all facies, in a range of $24 \%-49 \%$ (averaging 34.8\%) (Figure 2). 
In comparison with North America and other parts of China, the intersalt shale series of the Qianjiang Formation is characterized by lower clay minerals, lower quartz and feldspar and higher carbonates [14]. In brittle mineral content, the rhythmic target layer Qian $3_{4}{ }^{10}$ tends to descend from argillaceous dolomite facies $\rightarrow$ argillaceous limestone facies $\rightarrow$ dolomitic mudstone facies $\rightarrow$ glauberite filling dolomitic mudstone facies. Owing to a good brittleness and fractibility, the argillaceous dolomite facies provides a favorable target zone of the rhythmic layer Qian $3{ }^{10}$ for hydrocarbon exploration.

\subsection{Development of Source Rocks}

In this paper, the development of the shale source rocks of the intersalt shale series was studied regarding organic abundance, type and maturity, so as to ascertain which type(s) of lithofacies can accomodate excellent source rock reservoirs.

\subsubsection{Organic Abundances}

In general, the organic abundance cannot only control the physical and chemical properties of shales, but also development of fractures in the shales, and more importantly, the oil content of the shales [15]. The dark shales of the intersalt shale series have high organic abundances, but which are different between different types of lithofacies, from in a range of $4.23 \%-6.38 \%$ (averaging $4.23 \%$ ) for the argillaceous dolomites (limestones), to $0.44 \%-5.71 \%$ (averaging $3.08 \%$ ) for the dolomitic mudstone facies, and even to $0.35 \%-5.06 \%$ (averaging $1.81 \%$ ) (Figure 2).

\subsubsection{Organic Types}

The organic type can somewhat determine the hydrocarbon-generating potential of the organic matter, and also affect the occurrence pattern and content of shale oil [15]. The microscopic kerogen compositions of the intersalt series consist of amorphous bacteria and lower biogenic algae organic matter [7]. The plots of pyrolytic peak temperature Tmax vs $\mathrm{HI}$ and HI vs OI indicate that the data points are mostly concentrated in the Types I and II1 interval (Figure 4), which
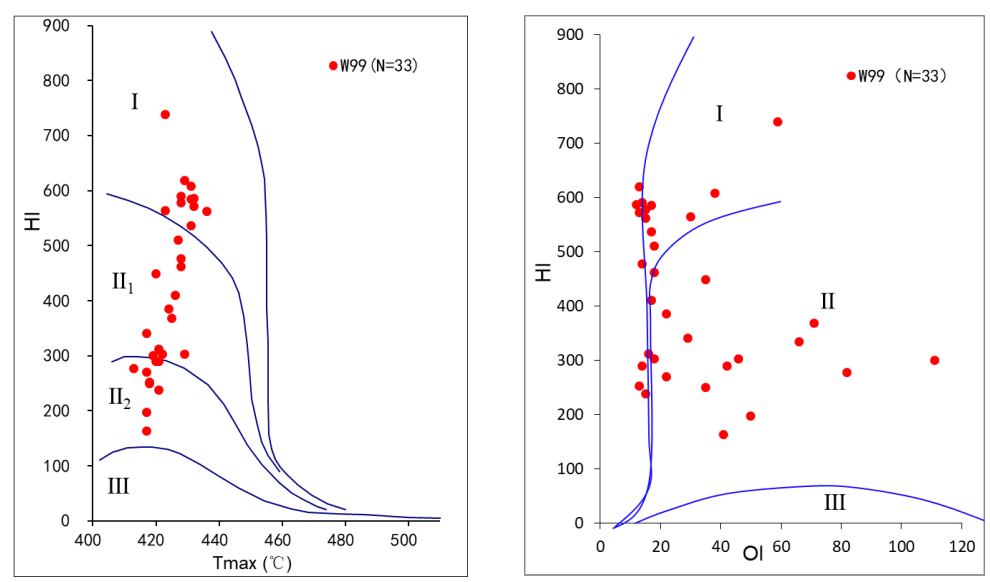

Figure 4. Plots of HI-Tmax and HI-OI for source rocks of the rhythmic layer Qian $34^{10}$ in Well W99. 
is consistent with the microscopic identification result. Various analysis results indicate that the Types I (sapropel type) and II 1 (sapropelic-humus type) represent the main kerogen types of the intersalt shale series, indicative of a great oil-generating potential.

\subsubsection{Organic Maturity}

The organic maturity is an important parameter to characterize its hydrocarbon-forming effectiveness and hydrocarbon properties. A number of methods can be used to evaluate the organic maturity, among which the vitrinite reflectance method is one of the most common and effective methods [15]. The rhythmic Qian $3{ }_{4}{ }^{10}$ shale has Ro values in a range of $0.48 \%-0.83 \%$, averaging $0.63 \%$, indicative of an entire thermal evolution degree as low as immature to undermature level. Laterally, Ro values tend to increase toward the Banghu Depression, and decrease to the Wangchang Anticline Belt. In addition, $\mathrm{T}_{\max }$ ranges from $300^{\circ} \mathrm{C}$ to $436^{\circ} \mathrm{C}$, averaging $418.7^{\circ} \mathrm{C}$, indicative of immature source rocks.

The above metioned parameters for evaluation of the development of the source rocks indicate that the intersalt shale series in the study area is characterized by high organic abundance, moderate organic types and thermal evolution degrees, indicative of a potential to generate a large volume of immature oils.

\subsection{Petrophysic Properties and Spaces of the Reservoir}

The comprehensive analysis on 18 core samples from Wells W99 and BYY2 pore, regrading porosity, permeability and structure data indicated that the intersalt shale series represented a superior type of lithofacies. In combination with observation and analyses with cathode luminescence, SEM and ordinary thin sections, the reservoir space types and development characteristics of intersalt shale were ascertained.

Petrophysic characteristics: Generally speaking, a great difference in porosity and less difference in permeability occur between different lithofacies types of the intersalt shale series in the study area (Figure 5), from argillaceous dolomites (limestones) as the best reservoir with porosities in a range of $10.78 \%-26.3 \%$ (averaging 15.96\%), and permeabilities, 0.05 - $23.68 \mathrm{md}$ (averaging $4.25 \mathrm{md}$ ) indicative of moderate porosity-extrolow permeability reservoir, to dolomitic mudstone facies as the moderate reservoir, with porosities in a range of $5.21 \%$ 23.83\% (averaging 10.98\%) and permeabilities 1.33 - 9.89 md (averaging 3.65 $\mathrm{md}$ ), indicative of low-porosity, extrolow-permeability reservoir, and to grauberite-filling dolomitic mudstone facies as the poorest reservoir, with porosities in a range of $3.58 \%-5.25 \%$ (averaging $4.42 \%$ ), indicative of extrolow-porosity reservoir (Figure 1 and Figure 5). In addition, the plot of porosity vs permeability shown in Figure 5 indicates that a poor function occurs between porosity and permeability for the dolomite reservoirs in the study area, indicative of a pore structure too poor to form a good-connectivity pore network. 


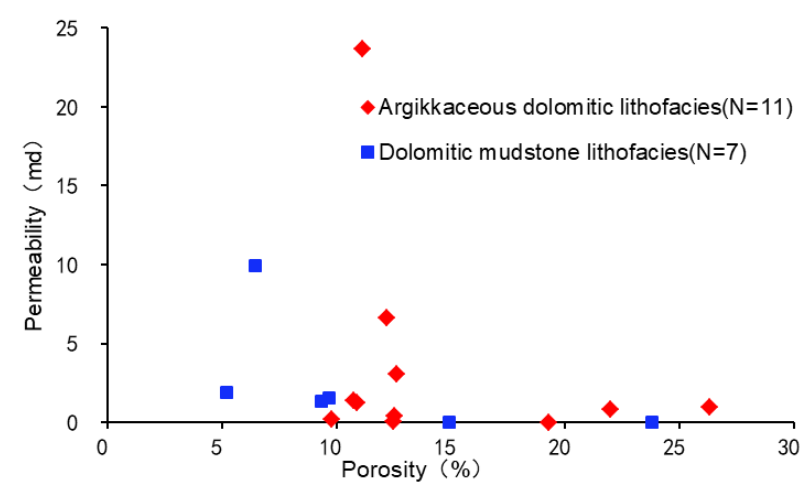

Figure 5. Plot of porosity vs permeability for the rhythmic layer Qian $34^{10}$ of the inter-salt shale series in Wells W99 and BYY2.

Reservoir space types and characteristics: With respect to the reservoir space types of the argillaceous dolomite facies and dolomite mudstone facies in the study area, pores are dominant, apart from few fractures. The pores consist of secondary intercrystalline pores as dominant, as well as rare intercrystalline dissolved pores. The intercrystalline pores are those occurring between xenomorphic micritic dolomite crystals, which belong to fabric selectivity pores. This type of rocks are mostly supported by crystal particles, and the intercrystalline spaces unfilled with cements provide good reservoir spaces, with pore sizes 2 - 4 um, in an irregular polyhedron shape and a poor structure (Figure 6(a) and Figure 6(b)). They contribute major reservoirs to the study area. The dissolution
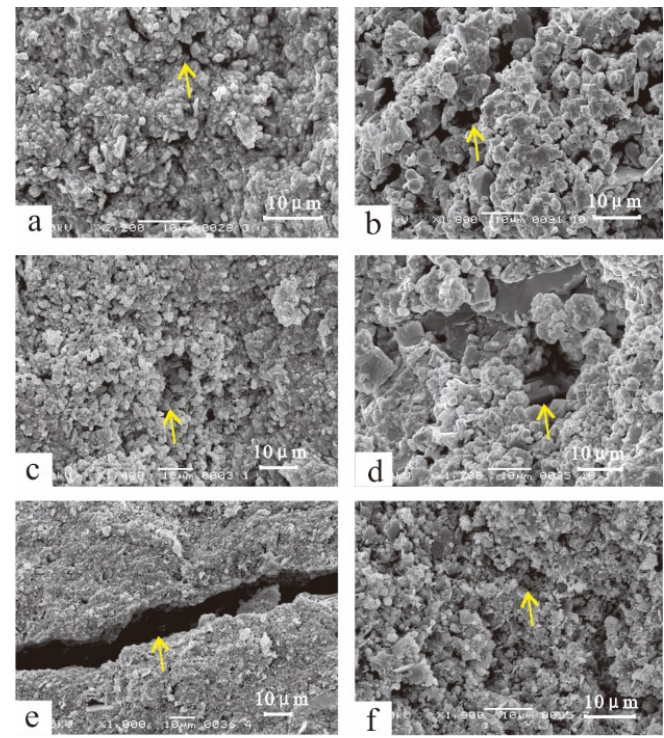

Figure 6. Shows the spatial types and characteristics of the dolomite reservoirs in the di3410 rhythmic strata in the study area. a. Intercrystalline pores, Well W99, carbon-rich dolomitic mudstone facies, $1679.7 \mathrm{~m}$, SEM; b. Intercrystalline pores, Well WY11, carbon-rich argillaceous dolomite facies, $1749.3 \mathrm{~m}$, SEM; c. Dissolution pores, Well W99, carbon-rich argillaceous dolomite facies, $1675.8 \mathrm{~m}$, SEM; d. Dissolution pores, Well WY11, carbon-rich argillaceous dolomite facies, $1749.3 \mathrm{~m}$, SEM; e. Structural fractures, Well W99, carbon-rich dolomitic mudstone facies, $1678.9 \mathrm{~m}$, SEM; f. Dissolution fractures, Well BYY2, carbon-rich argillaceous dolomite facies, $2821.3 \mathrm{~m}$, SEM. 
pores are resulted from dissolution and enlargement of the intergranular pores, in a highly irregular shape, with pore sizes 5 - 10 um usually greater than those of the dolomite crystals (Figure 6(c) and Figure 6(d)). The dissolution pores are rarely seen in the study area, providing less reservoir contribution due to a poor connectivity. Fractures in the study area are rarely seen, which can be divided into structural and dissolution ones, in terms of origin. The structural fractures are rarely seen and in a simplex type, such as high-angle straight fractures, with the internal fillings locally undissolved to form effective reservoir spaces (Figure 6(e)), so the structural fractures provide a less contribution to the reservoirs in the study area. The dissolution fractures are caused from dissolution and enlargement of the earlier structural fractures by fluids, with rugged walls, and in a wide range of widths. Their interiors are unfilled (Figure 6(f)). Their presences can often improve the local connectivity, but in a limited extent, so providing a limited contribution to the reservoirs.

\subsection{Characterization of Oil-Bearing Properties}

The intersalt shale seires are evaluated with respect to oil-bearing property by using both parameters S1 and S1/TOC. The parameter S1 obtained from the pyrolysis chromatographic analysis means the total hydrocarbon volume volatilzing from heated sample not exceeding $300^{\circ} \mathrm{C}$. The total hydrocarbons generally contain C7 - C33 hydrocarbons. The parameter S1/TOC may reflect the volume of free hydrocarbons. As indicated by the related research results in North America, a high oil saturation (S1/TOC) represents the shale oil resources with a productivity. S1/TOC greater than $100 \mathrm{mg}$ oil/g TOC means oil-productive [16]. In a whole, the intersalt shale series have a good oil-bearing property, with the S1/TOC values all over $100 \mathrm{mg}$ oil/g, but due to high internal heterogeneity, a great difference occurs between different lithofacies. The argillaceous dolomite facies was the best in oil-bearing property, with $\mathrm{S} 1$ values in a range of 3.48 - $5.64 \mathrm{mg} / \mathrm{g}$ (averaging $4.49 \mathrm{mg} / \mathrm{g}$ ) and S1/TOC values 348 - $564 \mathrm{mg}$ $\mathrm{oil} / \mathrm{g}$ (averaging $449 \mathrm{mg}$ oil/g). The argillaceous limestone facies are less different from the argillaceous dolomite facies, with $\mathrm{S} 1$ values in a range of $3.22-5.22$ $\mathrm{mg} / \mathrm{g}$ (averaging $4.45 \mathrm{mg} / \mathrm{g}$ ) and S1/TOC values $322-522 \mathrm{mg}$ oil/g (averaging $445 \mathrm{mg}$ oil/g).

The dolomitic mudstone facies is the secondary, with S1 values $2.25-4.99$ $\mathrm{mg} / \mathrm{g}$ (averaging $3.69 \mathrm{mg} / \mathrm{g}$ ) and S1/TOC values 225 - $498 \mathrm{mg}$ oil/g (averaging $369 \mathrm{mg}$ oil/g). The glauberite-filling dolomitic mudstone facies is the poorest in oil-bearing property, with S1 values $0.85-6.82 \mathrm{mg} / \mathrm{g}$ (averaging $3.41 \mathrm{mg} / \mathrm{g}$ ) and S1/TOC values 125 - $508 \mathrm{mg}$ oil/g (averaging $336 \mathrm{mg}$ oil/g).

In summary, the argillaceous dolomite facies of the intersalt shale series in the Qianjiang Depression is considered the most favorable facies type, which is characterized by good brittleness, hydrocarbon source rock characteristics, reservoir characteristics and oil-bearing property, and provide a key target interval for the coming exploration and development. 


\section{Conclusions}

1) The intersalt shale series in the Qianjiang Depression is characterized by high organic abundance, as well as fair organic matter type and thermal evolution level, indicative of potential generating a great volume of immature oil.

2) The rhythmic layer Qian $3{ }_{4}{ }^{10}$ in the Qianjiang Depression consists of argillaceous dolomite facies, argillaceous limestone facies, dolomitic mudstone facies, and calcium-mirabilite filling mudstone facies in terms of rock facies.

3) The argillaceous dolomite facies is the most contributory, with the reservoir spaces consisting of intercrystalline pores as dominant, as well as few dissolution pores and fractures. Owing to high content of brittle minerals, high organic abundance, high porosity and good oil-bearing properties, the argillaceous dolomite facies is considered the key target in the coming exploration and development efforts in the study area.

\section{Funded}

This paper is funded by the 2018 Undergraduate Training Program for Innovation and Entrepreneurship of Yangtze University, the project number is 2018267.

\section{Conflicts of Interest}

The authors declare no conflicts of interest regarding the publication of this paper.

\section{References}

[1] Zhang, L., Li, J., Li, Z., et al. (2014) Advances in Shale Oil/Gas Research in North America and Considerations on Exploration for Continental Shale Oil/Gas in China. Advances in Earth Science, 29, 700-711.

[2] Zhang, J., Lin, L., Li, Y., et al. (2012) Classification and Evaluation of Shale Oil. Earth Science Frontiers, 19, 322-331.

[3] Long, Y., Chen, M., Chen, F., et al. (2019) Characteristics and Influencing Factors of Inter-Salt Shale Oil Reservoirs in Qianjiang Formation, Qianjiang Depression. Petroleum Geology and Recovery Efficiency, 26, 59-64.

[4] Xiong, Z., Wu, S., Wang, Y., et al. (2015) Geological Characteristics and Practice for Intersalt Argillaceous Dolomites Reservoir in the Qianjiang Depression of Jianghan Salt Lake Basin. Geological Science and Technology Information, 34, 181-187.

[5] Li, L., Wang, Z., Zheng, Y., et al. (2019) Mechanism of Shale Oil Enrichment from the Salt Cyclotherm in Qian3 Member of Qianjiang Sag, Jianghan Basin. Earth Science, 44, 1012-1023.

[6] Wu, S.Q., Tang, X.S., Du, X.J., et al. (2013) Geologic Characteristics of Continental Shale Oil in the Qianjiang Depression, Jianghan Salt Lake Basin. Journal of Eeat China Institute of Technology (Natural Science), 36, 282-286.

[7] Chao, T.T., Ma, Y.Y., Li, M.W., et al. (2019) Hydrocarbon Characteristics of Inter-Salt System in Qian 3 Member of Qianjiang Sag, Jianghan Basin and Their Indication. Journal of Xi an Shiyou University (Natural Science Edition), 34, 25-30.

[8] Sun, Z.L., Wang, F.R., He, S., et al. (2019) The Pore Structures of the Shale about 
Typical Inter-Salt Rhythm in the Paleogene of Qianjiang Depression. Journal of Shenzheng University Science and Engineering, 36, 289-297.

[9] Fang, Z.X. (2002) Hydrocarbon Exploration Signification of Intersalt Sediments in Qianjiang Saline Lake Basin. Acta Sedimentologica Sinica, 20, 608-620.

[10] Wang, G.L., Yang, Y.Q., Zhang, Y.S., et al. (2004) Sedimentary Microfacies and Evolution of the Qianjiang Formation of Paleogene at Wangchang Area in Qianjiang Sag, Jianghan Basin. Journal of Palaeogeography, 6, 140-150.

[11] Xiao, F., Zhang, S.W., He, Y.B., et al. (2017) Geochemistry and Oil-Source Study of Inter-Salt Shale Oil of Eq3 in Qianjiang Depression. China Energy and Environmental Protection, 39, 96-101+108.

[12] Chen, B., Xiao, Q.G., Cao, W.S., et al. (2007) Exploration Potential Contrast of Non-Sandstone Reservoir within Salt-Layers between Shashi and Qianjiang Formations, Jianghan Basin. Petroleum Exploration and Development, 34, 190-196.

[13] Shen, J.J. (2015) Mechanism for Formation of Lacustrine Dolomites of the Lower Xingouzui Formation in the Southern Part of the Qianjiang Deprssion and Its Petroleum Geologic Implication. Yangtze University, đingzhou.

[14] Wang, F.R., He, S., Zheng, Y.H., et al. (2016) Mineral Composition and Brittleness Characteristics of the Inter-Salt Shale Oil Reservoirs in the Qianjiang Formation, Qianjiang Depression. Petroleum Geology and Experiment, 38, 211-218.

[15] Li, W.J., Zhang, J.C., Jing, T.Y., et al. (2014) Shale Oil Accumulation Conditions and Optimization of Favorable Areas in the West Liaohe Depression. Special Oil and Gas Reservoirs, 21, 59-65.

[16] Jarvie, D.M., Hill, R.J., Ruble, T.E. and Pollastro, R.M. (2007) Unconbentional Shale Gas Systems: The Mississippian Barnett Shale of North-Central Texas as One Model for Themogenic Shale-Gas System. AAPG Bulletin, 91, 475-499.

https://doi.org/10.1306/12190606068 